\title{
Penerapan Backward Design Model Dalam Matakuliah Basic Science Untuk Meningkatkan Literasi Guna Membangun Wawasan Kristen Alkitabiah
}

\author{
Kurniawati Martha \\ Universitas Pelita Harapan, Tangerang \\ kurniawati.martha@,uph.edu
}

\begin{abstract}
Technology helps us to get information in a short time. With an internet connection, we can easily get any information. But there is an emergency literacy problem in Indonesia. The question that arises in the minds of researcher is, "How could this happen, a country with $2^{\text {nd }}$ largest number of libraries in the world experiencing a literacy emergency?" However, it turns out that what is meant by literacy is more than just reading and writing. Literacy is the ability to interpret information critically so that everyone can access science and technology as an effort to improve the quality of life. Therefore, it must be realized the importance of the role of Christian educators in contributing to improving students' literacy skills in order to build an understanding of the biblical worldview. The researcher tries to use the Back Design Model to improve students' literacy skill. The research method is descriptive qualitative method. Subjects were Teachers College students from Christian Religious Education and Social Sciences study programs in the Basic Science courses. The researcher applies the Backward Design Model with the stages: Determining Learning Goals and Targets (determining objectives), Assessment Planning and Learning Activity Planning. These stages are proven to be able to improve the literacy skills of students who take Basic Sciences courses, namely in increasing reading interest, giving awareness to students to choose unreliable sources and honing students' abilities to criticize problems assigned by lecturers on the basis of on biblical Christian worldview.
\end{abstract}

Keywords: Literacy; Biblical Christian Worldview; Backward Design Model.

\begin{abstract}
Abstrak
Teknologi membantu kita mendapatkan informasi dalam waktu singkat. Dengan koneksi internet, kita bisa dengan mudah mendapatkan informasi apapun. Tetapi ada masalah darurat literasi di Indonesia. Pertanyaan yang muncul di benak peneliti adalah, "Bagaimana mungkin Indonesia, negara dengan jumlah perpustakaan terbanyak ke-2 di dunia, mengalami darurat literasi?" Namun ternyata yang dimaksud dengan literasi lebih dari sekedar membaca dan menulis. Literasi adalah kemampuan menafsirkan informasi secara kritis sehingga setiap orang dapat mengakses ilmu pengetahuan dan teknologi sebagai upaya meningkatan kualitas hidup. Oleh karena itu, perlu disadari pentingnya peran pendidik Kristen dalam berkontribusi untuk
\end{abstract}


meningkatkan keterampilan literasi peserta didik guna membangun pemahaman tentang wawasan Kristen Alkitabiah. Peneliti mencoba menggunakan Backward Design Model untuk meningkatkan kemampuan literasi mahasiswa. Metode yang digunakan adalah metode kualitatif deskriptif. Subjek penelitian adalah mahasiswa Teachers College program studi Pendidikan Agama Kristen dan Ilmu Sosial pada mata kuliah Basic Science. Peneliti menerapkan Model Backward Design dengan tahapan: Menentukan Tujuan dan Target Pembelajaran (menentukan tujuan), Perencanaan Penilaian dan Perencanaan Kegiatan Pembelajaran. Tahapan-tahapan tersebut terbukti mampu meningkatkan kemampuan literasi mahasiswa yang mengambil mata kuliah Basic Science yaitu dalam meningkatkan minat baca, memberikan kesadaran kepada mahasiswa untuk memilih sumber yang dapat dipercaya dan mengasah kemampuan mahasiswa untuk mengkritisi masalah yang ditugaskan oleh dosen dengan berdasarkan pada wawasan Kristen Alkitabiah.

Kata Kunci: Literasi; Wawasan Kristen Alkitabiah; Back Ward Design Model

\section{PENDAHULUAN}

Dengan adanya kemajuan teknologi yang berkembang saat ini, mencari dan mendapatkan informasi adalah hal yang sangat mudah. Hanya dengan menggunakan HP atau Laptop yang terkoneksi dengan internet, maka informasi apa pun dapat dengan mudah kita dapatkan. Hanya dalam hitungan menit, informasi yang baru saja terjadi di suatu tempat, sudah langsung muncul di media elektronik dan dapat langsung diketahui oleh banyak orang. Hal ini seharusnya bisa menjadi keuntungan karena manusia menjadi terhubung dan tidak lagi dibatasi oleh jarak atau wilayah tertentu sehingga permasalahan yang terjadi di suatu daerah terpencil (misalnya bencana alam atau masalah lingkungan) dapat segera

\footnotetext{
${ }^{1}$ GenPI.co, "Indonesia Darurat Literasi?," 2019, https:/www.genpi.co/gaya-
}

diketahui oleh pihak-pihak terkait dan bahkan sampai ke pemerintah pusat.

Walaupun ada keuntungan, perlu juga disadari bahwa tidak semua informasi dapat dipercaya dan dipertanggungjawabkan. Dengan banyaknya informasi maka perlu adanya kecakapan untuk memilih dan menentukan informasi secara bijak karena tidak semua informasi bisa digunakan dan dapat dipertanggungjawabkan kebenarannya.

Dalam kondisi banjir informasi yang terjadi saat ini, muncul isu bahwa Indonesia mengalami darurat literasi. ${ }^{1} \mathrm{Hal}$ ini sangat menyentak karena berdasarkan informasi dari akun Facebook Perpusnas, disampaikan bahwa Indonesia menempati peringkat ke-2 sebagai negara dengan jumlah perpustakaan terbanyak di dunia. ${ }^{2}$

hidup/9130/indonesia-darurat-literasi.

2 Perpusnas, "Indonesia Peringkat Ke-2 
Dua berita tersebut sangat kontradiktif, karena negara dengan jumlah perpustakaan terbanyak ternyata mengalami darurat literasi.

Dari sambutan Menteri Pendidikan dan Kebudayaan, Bapak Muhajir Effendy, disampaikan bahwa "Bangsa yang besar ditandai dengan masyarakatnya yang literat, yang memiliki peradaban tinggi, dan aktif memajukan masyarakat dunia. Keberliterasian dalam konteks ini bukan hanya masalah suatu bangsa bebas dari buta aksara, melainkan juga yang lebih penting, bagaimana warga bangsa memiliki kecakapan hidup agar mampu bersaing dan bersanding dengan bangsa lain untuk menciptakan kesejahteraan dunia". 3 Pernyataan Bapak Muhajir Effendy tersebut makin memperjelas bahwa literasi bukan hanya masalah yang berkaitan dengan buta aksara. Secara umum, istilah literasi biasanya hanya dikaitkan pada kemampuan seseorang dalam membaca dan menulis.

Berdasarkan penjelasan dalam website Kementerian Pendidikan dan

Negara Dengan Jumlah Perpustakaan Terbanyak Dunia," perpusnas.go.id, 2018, https://msmy.facebook.com/ayokeperpusnas/posts/sahabatper pusnastahukah-kamu-saat-ini-ada-164610perpustakaan-yang-tersebar-di3/3039897236050643/.

3 Muhadjir Effendy, "Materi Pendukung Literasi Budaya Dan Kewargaan," Pub. L. No. implementasi dari Peraturan Menteri Pendidikan dan Kebudayaan Nomor 23 Tahun 2015 (2017).

${ }^{4}$ Kementerian Pendidikan dan Kebudayaan,
Kebudayaan $^{4}$, pengertian literasi baca tulis tidak sebatas hanya kemampuan membaca, dan dijelaskan dalam gambar berikut.

Gambar 1. "Apakah literasi baca tulis?"

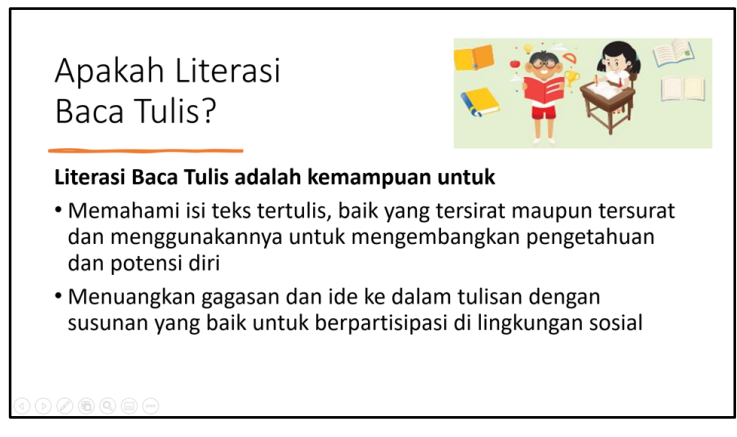

Menurut Anggraeni, dijelaskan bahwa "Literasi lebih dari sekedar membaca dan menulis. Literasi juga mencakup bagaimana seseorang berkomunikasi dalam masyarakat. ${ }^{5}$ Literasi juga bermakna praktik dan hubungan sosial yang terkait dengan pengetahuan, bahasa, dan budaya." Berdasarkan pasal 1 ayat (4) Undang-undang nomor 3 Tahun 2017 tentang Perbukuan dijelaskan bahwa Literasi adalah kemampuan untuk memaknai informasi secara kritis sehingga setiap orang dapat mengakses ilmu pengetahuan dan teknologi sebagai upaya dalam meningkatkan kualitas hidupnya. ${ }^{6}$

“Infografik Literasi Baca Tulis,” n.d.

${ }^{5}$ Prastika Ririt Anggraeni, "Implementasi Kebijakan Literasi Sekolah Guna Peningkatan Karakter Gemar Membaca," Indonesian Journal of Sociology, Education, and Development 1, no. 2 (December 10, 2019): 132-42, https://doi.org/10.52483/ijsed.v1i2.12.

6 Presiden, "Undang-Undang Republik Indonesia Tentang Sistem Perbukuan," Pub. L. No. Nomor 3/2017 (2017). 
Dengan memahami pengertian literasi ini, maka literasi adalah kemampuan yang perlu diperhatikan dan dikembangkan. Berdasarkan penjelasan dari Menteri Pendidikan Indonesia disampaikan bahwa literasi dasar adalah salah satu kecakapan yang dibutuhkan di abad ke-21. ${ }^{7}$

Agar dapat mengembangkan kemampuan literasi dasar, salah satu hal penting yang perlu diperhatikan adalah bagaimana bisa menumbuhkan minat baca. Menurut Kasali, beberapa elemen yang menjadi penyebab turunnya minat baca ${ }^{8}$, adalah:

- parenting, di mana anak tidak dibiasakan untuk memiliki budaya untuk membaca. Hal ini menyebabkan kemampuan membaca anak menjadi sangat rendah. Jika budaya membaca ini tidak segera ditindaklanjuti maka hal ini akan mempengaruhi kemampuan literasi anak hingga dewasa, bahkan ketika menjadi mahasiswa. ${ }^{9} \mathrm{C}$. Rini dalam penelitiannya melakukan analisis kemampuan literasi sains terhadap mahasiswa program studi PGSD FKIP Universitas Muhammadiyah Tangerang (UMT) di mana hasilnya pada indikator

\footnotetext{
${ }^{7}$ Gatra, "Mendikbud Ingatkan Pentingnya Literasi Di Abad 21," Gatra.com, n.d., https://www.gatra.com/detail/news/408564-

Mendikbud-Ingatkan-Pentingnya-Literasi-di-Abad21.

${ }^{8}$ GenPI.co, "Indonesia Darurat Literasi?"

9 Candra Puspita Rini, Saktian Dwi Hartantri, and Aam Amaliyah, "Analisis Kemampuan Literasi Sains Pada Aspek Kompetensi
}

menjelaskan fenomena ilmiah masuk dalam kategori "rendah", dan pada indikator mengidentifikasi pertanyaan atau isu-isu ilmiah dan indikator menggunakan bukti ilmiah, masuk dalam kategori “cukup". Hal ini tentunya akan berpengaruh terhadap proses pembelajaran sains (IPA) di sekolah dasar jika tidak dilakukan pembenahan dalam pengembangan kemampuan literasi pada mahasiswa.

- teknologi, di mana saat ini tidak jarang ditemukan informasi yang salah karena buku bacaan yang hadir dalam buku fisik digantikan oleh bacaan-bacaan dengan framing yang cenderung menjadi datar dan tidak dalam. Hal ini terjadi ketika seseorang hanya tertarik membaca berita populer yang membanjiri media online yang sebenarnya masih perlu dikaji. Banyaknya informasi akan dapat membingungkan/ menyesatkan jika pembacanya tidak memiliki kemampuan literasi yang baik. ${ }^{10}$ Rahadi dalam penelitiannya terhadap civitas akademika President University menjelaskan bahwa perilaku pengguna

Mahasiswa PGSD FKIP Universitas Muhammadiyah Tangerang," Jurnal Pendidikan Dasar Nusantara 6, no. 2 (January 30, 2021): 16679, https://doi.org/10.29407/jpdn.v6i2.15320.

${ }^{10}$ Dedi Rianto Rahadi, "Perilaku Pengguna Dan Informasi Hoax Di Media Sosial," Jurnal Manajemen Dan Kewirausahaan 5, no. 1 (June 30, 2017), https://doi.org/10.26905/jmdk.v5i1.1342. 
media sosial sangat dipengaruhi oleh latar belakang penggunanya. Perlu ada kesadaran bahwa berita hoax jika dibiarkan akan dapat memecah belah bangsa. Berita hoax juga dapat mencemarkan nama baik dari seseorang maupun institusi, seperti yang dialami oleh media online Merdeka ${ }^{11}$ Oleh karena itu, Rahadi menyampaikan sangat diperlukan dukungan pemerintah dan orangtua untuk meningkatkan kemampuan literasi agar masyarakat mampu mengenali ciri-ciri berita hoax, mampu mengakses berita yang benar, mampu menganalisis, mengevaluasi dan mampu mendapatkan makna yang tepat dari suatu berita.

Gambar 2. Contoh informasi hoax ${ }^{12}$
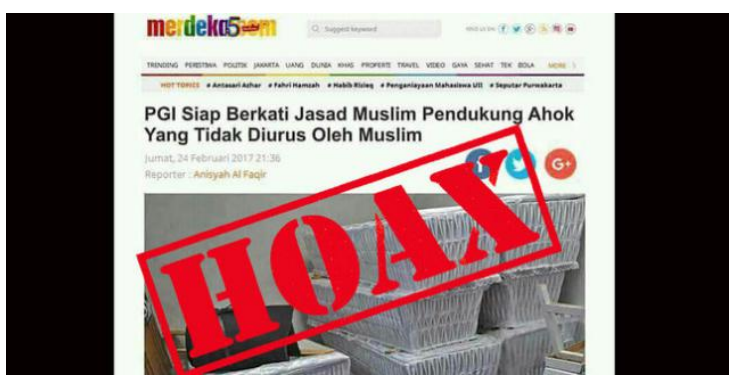

Untuk mengatasi hal ini, Kasali menganggap perlu adanya deep learning atau membaca lebih dalam. Dunia

11 Ramadhian Fadillah, "Berita HOAX Catut Merdeka.Com: 'PGI Berkati Jenazah Pendukung Ahok,", Merdeka, 2017, https://www.merdeka.com/peristiwa/berita-hoaxcatut-merdekacom-pgi-berkati-jenazah-pendukungahok.html.

12 Fadillah.

13 GenPI.co, "Indonesia Darurat Literasi?" pendidikan harus memberikan pengetahuan dasar untuk mengembangkan kepekaan terhadap berbagai jenis literasi, seperti membaca, menulis, berfikir dan merasakan objek di sekitarnya. ${ }^{13}$. Andrianti dalam tulisannya menuliskan definisi literasi menurut Kusumadewi ${ }^{14}$, yaitu sebagai proses belajar sepanjang masa (life-long learning) agar dapat menjadi subjek, yang memiliki karakter manusia yang bijak, kritis, kreatif, dan peduli serta dapat bersimpati, berempati, dan berkompati (compathy) pada diri, sesama serta lingkungan hidupnya.

Dengan memperhatikan pentingnya kemampuan pengembangan literasi ini, maka penulis menerapkan Backward Design Model dalam merancang penilaian dan kegiatan perkuliahan dalam mata kuliah Basic Science yang diikuti oleh mahasiswa Teachers Colllege Program Studi PAK (Pendidikan Agama Kristen) dan Program Studi IPS (Ilmu Pengetahuan Sosial), di mana semua mahasiswa dipersiapkan menjadi guru-guru Kristen. Oleh kerena itu, setiap mahasiswa seharusnya memiliki Wawasan Kristen

\footnotetext{
14 Sarah Andrianti, "Peran Guru PAK Sebagai Fasilitator Dalam Pelaksanaan Pembelajaran Literasi," FIDEI (ISSN: 2621-8135) 1, no. 2 (2018), https://media.neliti.com/media/publications/270034 -peran-guru-pendidikan-agama-kristen-sebab862a162.pdf.
} 
Alkitabiah. Penulis melihat kemampuan literasi yang baik akan dapat menuntun dan mengembangkan kemampuan mahasiswa program studi PAK dan program studi IPS agar mampu menjadi guru-guru Kristen yang dapat mengevaluasi wawasan dunia yang lain, termasuk isu-isu dalam Science (termasuk Sosial Science) berdasarkan Wawasan Dunia Kristen (Wawasan Kristen Alkitabiah). Dengan dimilikinya kemampuan literasi diharapkan akan memperlengkapi para calon guru Kristen Prodi PAK dan Prodi IPS dalam menjalankan pendidikan Kristiani sehingga mereka dapat membimbing siswa mereka menjalani hidup secara Kristiani, yang mampu berkomitmen mengembangkan dan mengaplikasikan pengetahuannya untuk berkontribusi bagi sesama dan Kerajaan Allah. ${ }^{15}$

\section{METODE PENELITIAN}

Penelitian yang dilakukan mengunakan metode deskriptif kualitatif. Subjek penelitian adalah mahasiswa Teachers College UPH yang semuanya beragama Kristen, yang terdiri dari 19 mahasiswa dari prodi Pendidikan Agama Kristen (PAK) dan 16 mahasiswa prodi Ilmu Pengetahuan Sosial (IPS) yang

${ }^{15}$ Harro Van Brummelen, "Ruang Kelas Kita: Ruang Milik Allah," Transforming 15, no. mengikuti mata kuliah Basic Science yang dilakukan pada semester 1 tahun ajaran 2020/2021. Pengumpulan data dilakukan dengan menganalisis angket online yang dibagikan ke mahasiswa pada sesi awal perkuliahan (minggu 1) dan angket online yang dibagikan ke mahasiswa pada sesi terakhir (minggu ke 16). Tujuan dibagikannya angket online di awal dan di akhir perkuliahan adalah untuk mengukur efektifitas penerapan Backward Design Model guna meningkatkan kemampuan literasi mahasiswa dalam mata kuliah Basic Science. Dosen juga melakukan observasi dan evaluasi penilaian di sepanjang perkuliahan dengan berdasarkan rubrik penilaian presentasi (mulai minggu ke 3 sampai minggu ke 9 sebagai penilaian UTS), dan rubrik penilaian penulisan paper (UAS) di mana di dalamnya ada kriteria penilaian agar mahasiswa dapat mengembangkan kemampuan literasinya.

\section{HASIL PENELITIAN DAN PEMBAHASAN}

Kemampuan literasi adalah kemampuan yang perlu dimiliki dan dikembangkan. Namun sayangnya belum semua orang memiliki kesempatan untuk bisa mengembangkannya dengan maksimal karena banyak faktor seperti misalnya pola asuh orangtua. Penelitian yang dilakukan oleh Rini terhadap kemampuan literasi

Christian Education (2014): 15-18, http://acsi.or.id. 
sains mahasiswa program studi PGSD FKIP Universitas Muhammadiyah Tangerang (UMT) menunjukkan hasil adanya kategori "rendah" pada indikator menjelaskan fenomena ilmiah dan kategori "cukup" pada indikator mengidentifikasi pertanyaan atau isu-isu ilmiah dan indikator menggunakan bukti ilmiah, Kemampuan mahasiswa PGSD yang adalah calon guru $\mathrm{SD}$, tentunya akan berpengaruh terhadap proses pembelajaran sains (IPA) di sekolah dasar jika tidak dilakukan pembenahan dalam pengembangan kemampuan literasi pada mahasiswa ${ }^{16}$.

Melihat fenomena di mana kemampuan literasi mahasiswa juga bervariasi dan perlu juga dikembangkan, maka penulis yang juga adalah pengajar calon guru merasakan perlunya untuk secara khusus merancang perkuliahan dan penilaian guna meningkatkan kemampuan literasi mahasiswa. Oleh karena itu, mata kuliah Basic Science dirancang dengan menerapkan Backward Design Model.

Untuk mendapatkan gambaran mengenai minat baca mahasiswa, sesi pertama perkuliahan, mahasiswa Prodi PAK dan IPS, diminta mengisi angket secara online. Dari angket yang dikumpulkan, diperoleh data bahwa 52\% mahasiswa sebenarnya tidak memiliki hobi

16 Rini, Dwi Hartantri, and Amaliyah, “Analisis Kemampuan Literasi Sains Pada Aspek membaca. Data ini diperoleh berdasarkan jawaban mahasiswa yang mengisi kuesioner di mana 12 mahasiswa menjawab memiliki hobi membaca dan 13 mahasiswa menjawab tidak memiliki hobi membaca.

Bagan 1. Data Mahasiswa yang memiliki Hobi Membaca

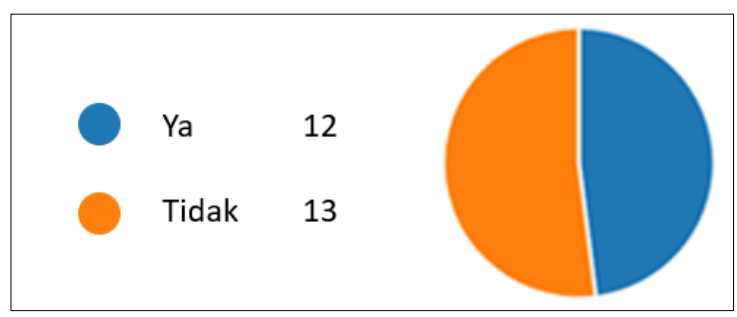

Saat mendapati data di perkuliahan pertama, penulis melihat hal ini menjadi tantangan bagi penulis untuk memikirkan rancangan pembelajaran yang mampu mendorong dan memotivasi atau mahasiswa meningkatkan kemampuan literasi mereka.

Berdasarkan data pada Bagan 1 maka penulis menambahkan kriteria dalam rubrik penilaian dan memastikan proses perkuliahan Basic Science setiap sesinya benar-benar efektif guna meningkatkan kemampuan Literasi mahasiswa. Tugas yang diberikan kepada mahasiswa sudah dipikirkan dengan seksama agar benarbenar dapat mendorong mahasiswa melakukan deep learning dan membaca sejumlah bahan bacaan di mana hal ini juga Muhammadiyah Tangerang." 
menjadi salah satu kriteria dalam rubrik penilaian.

Adapun penerapan "Backward Design Model" adalah sebagai berikut.

\section{Gambar 2. Backward Design Model}

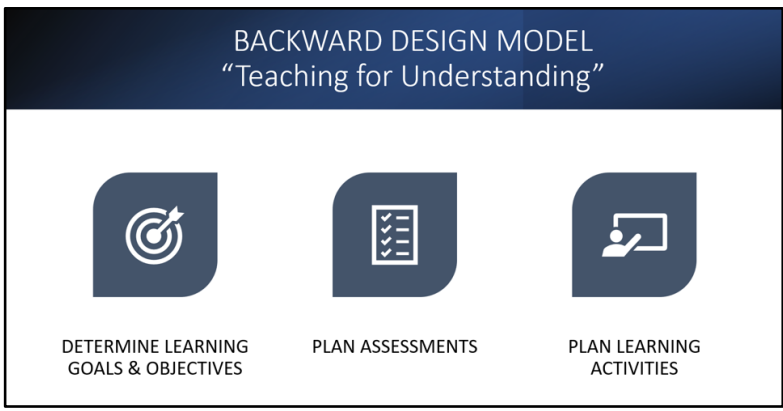

Sesuai dengan "Backward Design Model" 17, maka langkah-langkah yang dilakukan peneliti dalam mendesain pembelajaran di mata kuliah Basic Science adalah:

\section{Determine Learning Goals and Objectives:}

Langkah pertama yang peneliti lakukan adalah dengan menentukan tujuan dari perkuliahan mata kuliah Basic Science. Oleh karena itu, peneliti yang juga adalah pengajar dalam mata kuliah Basic Science melakukan kajian dengan menetapkan Capaian Pembelajaran Mata Kuliah (CPMK) yang sudah ditetapkan oleh fakultas sebagai tujuan dari perkuliahan.

Adapun CPMK Basic Science adalah:

- Mahasiswa mampu menjelaskan ruang lingkup sains dasar
- Mahasiswa mampu menjelaskan alam pikir manusia dan perkembangannya sebagai ciptaan Tuhan tertinggi

- Mahasiswa mampu menjelaskan perkembangan sains melalui metode ilmiah dan perkembangan daya abstraksi manusia

- Mahasiswa mampu menerapkan prinsip-prinsip dari sains untuk memecahkan masalah didasarkan pada perspektif Kristen

- Mahasiswa mampu menganalisis bagaimana penemuan dan perkembangan dalam ilmu sains dan teknologi berhubungan dengan kehidupan sehari-hari

Agar tujuan-tujuan tersebut dapat tercapai, peneliti melihat bahwa kemampuan literasi sangat diperlukan terutama untuk memperlengkapi mahasiswa dalam menganalisis dan menerapkan prinsip-prinsip sains untuk memecahkan masalah didasarkan pada perspektif Wawasan Kristen Alkitabiah. Oleh karena itu dalam perkuliahan Basic Science, usaha untuk meningkatkan kemampuan literasi mahasiswa juga menjadi tujuan perkuliahan.

\section{Plan Assesments.}

https://www.rochester.edu/college/cetl/faculty/onli ne/backward.html. 
Untuk mencapai CPMK Basic Science dan meningkatkan kemampuan literasi, maka peneliti memikirkan perencanaan penilaian:

- UTS: Mencari informasi di media cetak dan atau media elektronik mengenai perkembangan sains melalui teknologi saat ini, dan menganalisis dampaknya terhadap peradaban manusia. Tugas tersebut dikerjakan di dalam kelompok dan dipresentasikan mulai minggu ke 3 sampai minggu ke 9.

- UAS, yaitu dengan melakukan observasi dan menganalisis kondisi lingkungan dan pengelolaan sumber daya alam di tempat mahasiswa tinggal. Setelah itu meminta mahasiswa memikirkan solusi yang dapat dilakukan untuk memperbaiki atau meningkatkannya sesuai dengan mandat budaya yang sesuai dengan kebenaran Firman Tuhan (dengan menerapkan metode ilmiah dan studi literatur). Mahasiswa membuat laporan kegiatan dan mempresentasikannya di dalam kelompok. Kegiatan presentasi dilakukan mulai minggu ke 10 sampai minggu ke 16.

Tugas UTS dan UAS dibuat

18 Putra Andreas Maurenis, "Kristen Dan Teknologi: Etika, Literasi Dan Ciptaan: Christianity menantang dan kontekstual dengan meminta mahasiswa mencari perkembangan sains dan teknologi yang update untuk kemudian dianalisis sesuai dengan wawasan Kristen Alkitabiah. Harapannya melalui penilaian UTS dan UAS, mahasiswa dikondisikan untuk mencari informasi melalu media cetak dan atau media elektronik sehingga diharapkan ada peningkatan kemampuan literasi mahasiswa. Untuk melakukan kajian wawasan Kristen Alkitabiah, mahasiswa juga diminta untuk mencari sumber pendukung dari kajian yang dibuatnya. Di dalam rubrik penilaian juga ada kriteria penilaian mengenai pentingnya adanya teori pendukung yang tepat untuk mendukung argumen/pembahasan yang dilakukan.

Menurut Maurenis, dengan adanya kesadaran beretika, kemampuan literasi, dan kesadaran sebagai makhluk ciptaan Tuhan yang cerdas maka umat Kristiani dalam berbagai dinamika hidup diharapkan mampu memperlihatkan sebuah etika dan spiritualitas manusia, terutama dalam konteks etika dan spiritualitas Kristiani". ${ }^{18}$ Hal ini menjelaskan bahwa kemampuan literasi sangat dibutuhkan Jurnal Teologi Amreta (ISSN: 2599-3100) 3, no. 2 
agar mahasiswa dapat melakukan kajian wawasan Kristen Alkitabiah yang dapat dipertanggungjawabkan.

Di perkuliahan Basic Science, mahasiswa dikembangkan kemampuan literasinya agar dapat melihat perkembangan sains dan teknologi sebagai anugerah dari Tuhan sehingga pemahaman ini akan dapat membangun kesadaran manusia dari dalam dirinya tentang kebaikan dan kebijaksanaan Tuhan dalam setiap kreasi dan inovasi dalam hal sains dan teknologi. Hal ini juga didukung dengan adanya rubrik penilaian di mana salah satu kriteria yang dinilai adalah di bagian pembahasan, di mana mahasiswa diharapkan mampu menyajikan minimal 3 bukti hasil observasi berdasarkan langkah-langkah metode ilmiah dan menganalisisnya berdasarkan prinsip Alkitabiah yang didukung minimal 2 teori yang tepat. Tentunya agar mahasiswa dapat mengerjakan paper tugas akhir dengan maksimal, maka kemampuan literasi sangat dibutuhkan untuk mendapatkan minimal 2 teori yang mendukung dalam menganalisis berdasarkan wawasan Kristen Alkitabiah. Harapannya dengan hal ini, maka kemampuan literasi mahasiswa akan meningkat

${ }^{19}$ Harro Van Brummelen, Batu Loncatan sehingga pemahaman mahasiswa akan wawasan Kristen Alkitabiah juga akan makin baik. Mengapa memiliki pemahaman wawasan Kristen Alkitabiah menjadi hal yang penting? Brummelen, menyatakan bahwa," guruguru akan selalu mengajarkan sesuatu yang melebihi fakta pengajaran, karena guru akan memberikan pandangan dan pendapat pribadi mereka." ${ }^{19}$ Hal ini menunjukkan bahwa guru tidak mungkin bersikap netral pada saat mengajar. Hal ini akan membuat pengajaran di ruang-ruang kelas menjadi tidak netral.

Oleh karena itu, sebagai dosen yang mempersiapkan calon guru Kristen, tentunya menjadi hal yang penting untuk menekankan pentingnya memiliki wawasan Kristen Alkitabiah sehingga hal ini akan memperlengkapi mahasiswa agar mampu mengajar dan menggunakan ilmu pengetahuan untuk memuliakan Kristus dan makin menyadari anugerah yang diberikanNya. Hal ini dapat terjadi hanya jika setiap pendidik memiliki wawasan Kristen Alkitabiah. Sebagai contoh, ketika kita memiliki cara pandang bahwa dunia ini adalah milik Allah maka pada saat kita mengelola bumi maka akan dikelola dengan penuh Universitas Pelita Harapan Press, 2008). 
tanggung jawab bukan hanya bertanggungjawab kepada manusia namun yang terutama adalah kepada Allah.

\section{Plan Learning Activities}

Perencanaan perkuliahan dalam mata kuliah Basic Science mengikuti tahap-tahap pembelajaran Sains yang disampaikan oleh Maria Grant dan Diane Lapp yaitu ${ }^{20}$ :

\section{Mengidentifikasi topik sains yang} menarik dengan tujuan agar mahasiswa terhubung dengan dunia nyata dan lebih membuka diskusi. Dalam perkuliahan Basic Science, langkah-langkah tersebut diterapkan. Tugas ini menjadi menantang karena mahasiswa diberi kesempatan untuk menentukan permasalahan/topik Sains yang up-to-date dan yang diminatinya

2. Melibatkan mahasiswa dalam membaca penelitian dengan cara mendorong mahasiswa mencari informasi melalui berbagai teks yang berhubungan dengan topik dari berbagai sumber. Di sepanjang perkuliahan Basic Science, selain mahasiswa diminta membaca bahan

20 Maria Grant, “Teaching Science Literacy," Educational Leadership 68 No 6 (2011), http://www.ascd.org/publications/educational- yang diberikan dosen, mahasiswa diminta mencari sumber-sumber lain/hasil penelitian yang mendukung materi/permasalahan yang mereka pilih.

3. Mendorong mahasiswa untuk membaca seperti ilmuwan dengan cara mempelajari cara memahami teks sains seperti membaca grafik, bagan, tabel data, dan bagian analisis data, untuk kemudian menghubungkan informasi ini ke teks.

4. Membimbing mahasiswa untuk mengevaluasi data dengan mempertimbangkan berbagai sumber data agar didapatkan informasi yang benar, sehingga data yang dianalisis dan dipresentasikan adalah data yang valid dan dapat dipertanggungjawabkan.

Pemahaman mahasiswa juga dipertajam pada saat mereka presentasi melalui pertanyaan dan penjelasan yang disampaikan oleh dosen maupun oleh mahasiswa yang mengikuti mata kuliah Basic Science. Pada saat menjawab pertanyaan atau mengajukan pertanyaan, mahasiswa juga dilatih untuk berpikir kritis 
dengan memastikan apakah argumen/ pembahasan yang diberikan memiliki data yang akurat dan dapat dipertanggungjawabkan. Mahasiswa diminta untuk menunjukkan bukti dalam berargumen baik pada saat bertanya maupun menanggapi pertanyaan. Oleh karena itu kemampuan literasi sangat diperlukan dalam proses diskusi dan tanya jawab yang dilakukan. Untuk tugas UAS, setelah mahasiswa presentasi maka mahasiswa juga diminta untuk memperbaiki narasi atau mencari sumber yang lebih akurat untuk dituliskan di laporan UAS. Harapannya tugas UAS ini juga mendorong mahasiswa untuk dapat meningkatkan kemampuan literasinya dan dapat menganalisis permasalahan dengan berdasarkan Wawasan Kristen Alkitabiah.

Setelah mengikuti perkuliahan di kelas Basic Science selama 16 kali pertemuan yang dilakukan secara daring, mahasiswa diminta untuk mengisi kuesioner kembali. Jawaban seluruh mahasiswa yang mengisi kuesioner adalah mereka menjadi rajin membaca. Artinya melalui kegiatan perkuliahan yang menerapkan Backward Design Model, terbukti dapat membuat mahasiswa menjadi lebih rajin membaca. Hal ini dapat dilihat dari Bagan 2.
Bagan 2. Dampak Tugas yang diberikan terhadap Minat Baca

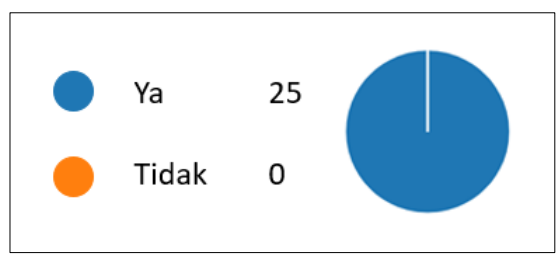

Berdasarkan hasil kuesioner, mahasiswa menyampaikan bahwa untuk menyelesaikan tugas Basic Science mereka membaca 6-10 sumber bacaan. Hal ini menunjukkan bahwa plan learning activities yang dirancang di kelas Basic Science terbukti dapat mendorong mahasiswa untuk meningkatkan kemampuan literasi. Adapun data mengenai hal ini dapat dilihat pada Bagan 3.

Bagan 3. Jumlah Sumber Bacaan yang dibaca Mahasiswa

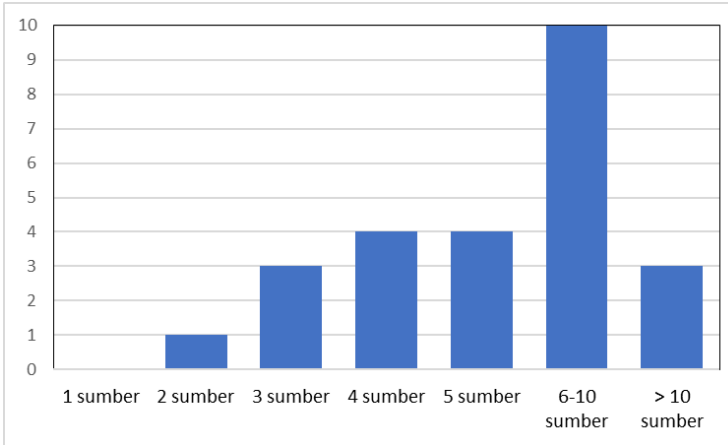

Hal lain yang menarik adalah bahwa mahasiswa yang sebelumnya menyatakan tidak memiliki hobi membaca, menyampaikan bahwa setelah mendapatkan tugas Basic Science, mereka menjadi lebih termotivasi untuk membaca sumber lain, selain dari bahan bacaan yang disediakan oleh dosen. Adapun data dari mahasiswa tersebut adalah sebagai berikut. 
- 3 mahasiswa membaca lebih dari 10 sumber bacaan.

- 10 mahasiswa membaca 6 - 10 sumber bacaan

- 4 mahasiswa membaca 5 sumber bacaan

- 4 mahasiswa membaca 4 sumber bacaan

- 3 mahasiswa membaca 3 sumber bacaan

- 1 mahasiswa membaca 2 sumber bacaan

Adanya perubahan khususnya untuk 2 mahasiswa yang tadinya tidak hobi membaca menjadi membaca lebih dari 10 sumber bacaan, dikarenakan:

- adanya dorongan secara internal dari mahasiswa untuk mendalami topik yang dibahas dalam perkuliahan di mana mahasiswa juga berkeinginan untuk dapat menjelaskan permasalahan secara jelas pada saat sesi diskusi

- adanya dorongan untuk memperoleh sumber yang valid dan menghindari subjektifitas sehingga dapat menjelaskan permasalahan secara jelas pada saat sesi diskusi

Kedua jawaban tersebut diperoleh berdasarkan jawaban yang disampaikan oleh kedua mahasiswa tersebut melalui kuesioner yang diberikan.

Sedangkan perubahan khususnya untuk 5 mahasiswa yang tadinya tidak hobi membaca menjadi membaca 6-10 sumber bacaan, dikarenakan:

- adanya dorongan untuk dapat menjelaskan topik yang dibahas dengan lebih jelas pada saat berdiskusi.

- Adanya kesadaran untuk mendapatkan data yang akurat sehingga membaca menjadi kebutuhan untuk mendapatkan banyak data agar dapat membandingkannya dan mengambil kesimpulan.

- Adanya kebutuhan untuk mendapatkan penjelasan atau informasi dari topik yang mereka observasi, sehingga dapat dipertanggungjawabkan pada saat presentasi

- Adanya kesadaran pentingnya memiliki kemampuan menganalisis permasalahan secara tepat sehingga merasa perlu didukung oleh banyak sumber dan terpercaya sehingga diperoleh kesimpulan pemahaman, saran dan solusi yang tepat dari permasalahan atau penelitian yang dilakukan.

- Adanya kesadaran untuk memperluas wawasan sehingga dapat melihat topik yang dibahas dari berbagai sisi.

Usaha mahasiswa untuk mendapatkan sumber informasi adalah dengan melakukan wawancara, observasi, mencari informasi melalui media cetak dan media online. Adapun hal ini dapat dilihat pada 
bagan berikut.

Bagan 4. Usaha mahasiswa untuk mendapatkan sumber informasi
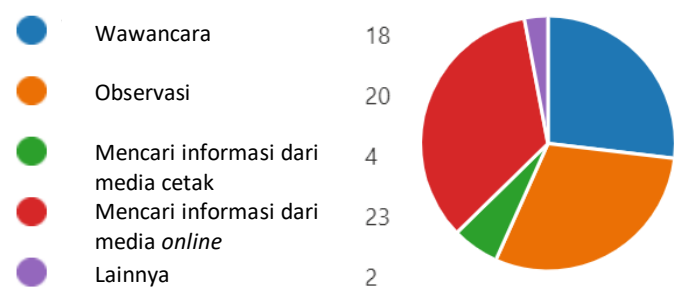

Dari Bagan 4 terlihat bahwa mencari informasi dengan media cetak dan media online adalah hal yang juga dilakukan mahasiswa untuk mendapatkan informasi.

Dengan adanya tuntutan dalam perkuliahan yang juga dituliskan di rubrik penilaian, di mana mahasiswa diharapkan mendapatkan informasi yang valid dan dapat dipertanggung-jawabkan, telah mendorong mahasiswa untuk mencari sumber yang dipercaya. Adapun jawaban mahasiswa yang menjelaskan bagaimana mereka memilih sumber bacaan yang dapat dipercaya adalah dengan menggunakan google schoolar, memilih bacaan yang dipercaya seperti .org, .id, memilih buku yang memiliki ISBN, atau jurnal yang sudah terpenuhi, kriteria (Volume, tahun, DOI, memiliki ISSN dll, tidak menggunakan domain website blogspot, wordpress, dll.

Jawaban mahasiswa tersebut menunjukkan adanya kesadaran mahasiswa untuk mendapatkan informasi yang tepat dan dapat dipertanggungjawabkan. Hal ini juga nampak di sepanjang diskusi saat presentasi dan tanya jawab, di mana mahasiswa juga menyertakan sumber pendukung saat menjawab dan mengajukan pertanyaan. Hal ini membuat diskusi menjadi berbobot dan memperkaya wawasan mahasiswa di mana hal ini nampak dalam paper yang dituliskan oleh mahasiswa. Mahasiswa juga mampu mengkritisi informasi yang diperolehnya dengan wawasan Kristen Alkitabiah.

Berdasarkan data-data tersebut maka terbukti bahwa penerapan Backward Design Model mampu meningkatkan kemampuan literasi mahasiswa dalam mata kuliah Basic Science.

\section{KESIMPULAN}

Literasi adalah kemampuan untuk memaknai informasi secara kritis sehingga setiap orang dapat mengakses ilmu pengetahuan dan teknologi sebagai upaya dalam meningkatkan kualitas hidupnya. Diharapkan dengan dimilikinya kemampuan literasi maka akan dapat menuntun dan mengembangkan kemampuan orang-orang yang percaya pada Kristus agar dapat mengevaluasi wawasan dunia yang lain berdasarkan Wawasan Dunia Kristen sehingga dapat menjadi garam dan terang dunia.

Oleh karena itu, sebagai pendidik (khususnya sebagai dosen) sangat penting untuk mendorong mahasiswa agar dapat 
meningkatkan kemampuan literasi mahasiswa sehingga mereka dapat menganalisis permasalahan dengan berdasarkan Wawasan Kristen Alkitabiah Dalam hal ini peneliti menerapkan Backward Design Model yaitu: Determine Learning Goals and Objectives (menentukan tujuan), Plan Assessments (Perencanaan Penilaian) dan Plan Learning Activities (Perencanaan aktivitas pembelajaran) yang terbukti dapat meningkatkan kemampuan literasi dan mengasah kemampuan mahasiswa untuk mengkritisi permasalahan yang ada sesuai dengan wawasan Kristen Alkitabiah.

\section{DAFTAR PUSTAKA}

Andrianti, Sarah. "Peran Guru PAK Sebagai Fasilitator Dalam Pelaksanaan Pembelajaran Literasi." FIDEI (ISSN: 2621-8135) 1, no. 2 (2018).

https://media.neliti.com/media/public ations/270034-peran-gurupendidikan-agama-kristen-sebab862a162.pdf.

Anggraeni, Prastika Ririt. "Implementasi

Kebijakan Literasi Sekolah Guna

Peningkatan Karakter Gemar

Membaca." Indonesian Journal of

Sociology, Education, and

Development 1, no. 2 (December 10, 2019): 132-42.

https://doi.org/10.52483/ijsed.v1i2.12

Brummelen, Harro Van. Batu Loncatan

Kurikulum Berdasarkan Alkitab.
Tangerang: Universitas Pelita Harapan Press, 2008.

. " Ruang Kelas Kita: Ruang Milik Allah." Transforming 15, no.

Christian Education (2014): 15-18. http://acsi.or.id.

Effendy, Muhadjir. Materi Pendukung literasi budaya dan kewargaan, Pub. L. No. implementasi dari Peraturan Menteri Pendidikan dan Kebudayaan Nomor 23 Tahun 2015 (2017).

Fadillah, Ramadhian. "Berita HOAX Catut Merdeka.Com: 'PGI Berkati Jenazah Pendukung Ahok."” Merdeka, 2017. https://www.merdeka.com/peristiwa/ berita-hoax-catut-merdekacom-pgiberkati-jenazah-pendukungahok.html.

Gatra. "Mendikbud Ingatkan Pentingnya Literasi Di Abad 21." Gatra.com, n.d. https://www.gatra.com/detail/news/40 8564-Mendikbud-IngatkanPentingnya-Literasi-di-Abad-21.

GenPI.co. "Indonesia Darurat Literasi?," 2019. https:/www.genpi.co/gayahidup/9130/indonesia-darurat-literasi.

Grant, Maria. "Teaching Science Literacy." Educational Leadership 68 No 6 (2011).

http://www.ascd.org/publications/edu cational-

leadership/mar11/vol68/num06/Teach ing-Science-Literacy.aspx.

Kementerian Pendidikan dan Kebudayaan. "Infografik Literasi Baca Tulis," n.d.

Maurenis, Putra Andreas. "Kristen Dan Teknologi: Etika, Literasi Dan Ciptaan: Christianity and Technology: Ethics, Literacy and 
Creation." Jurnal Teologi Amreta

(ISSN: 2599-3100) 3, no. 2 (2020):

101-23.

Perpusnas. "Indonesia Peringkat Ke-2

Negara Dengan Jumlah Perpustakaan

Terbanyak Dunia.” perpusnas.go.id,

2018. https://ms-

my.facebook.com/ayokeperpusnas/po

sts/sahabatperpusnastahukah-kamu-

saat-ini-ada-164610-perpustakaan-

yang-tersebar-di-

3/3039897236050643/.

Presiden. Undang-Undang Republik

Indonesia Tentang Sistem Perbukuan,

Pub. L. No. Nomor 3/2017 (2017).

Rahadi, Dedi Rianto. "Perilaku Pengguna

Dan Informasi Hoax Di Media

Sosial." Jurnal Manajemen Dan

Kewirausahaan 5, no. 1 (June 30,

2017).

https://doi.org/10.26905/jmdk.v5i1.13

42.

Rini, Candra Puspita, Saktian Dwi

Hartantri, and Aam Amaliyah.

“Analisis Kemampuan Literasi Sains

Pada Aspek Kompetensi Mahasiswa

PGSD FKIP Universitas

Muhammadiyah Tangerang." Jurnal

Pendidikan Dasar Nusantara 6, no. 2

(January 30, 2021): 166-79.

https://doi.org/10.29407/jpdn.v6i2.15

320.

University Rochester. "Backward Design."

Accessed April 6, 2021.

https://www.rochester.edu/college/cet

1/faculty/online/backward.html. 